\title{
A bio-economic approach to analyze the role of alternative seeding-harvesting schedules, water quality, stocking density and duration of cultivation in semi-intensive production of shrimp in Mexico
}

\author{
Margarita Estrada-Pérez ${ }^{1}$, Javier M.J. Ruiz-Velazco ${ }^{2}$ \\ Alfredo Hernandez-Llamas ${ }^{3}$ \& Iram Zavala-Leal ${ }^{2}$ \\ ${ }^{1}$ Programa de Posgrado en Ciencias Biológico Agropecuarias (CBAP), Universidad Autónoma de Nayarit \\ Cd. de La Cultura Amado Nervo s/n, Tepic, Nayarit 63255, Mexico \\ ${ }^{2}$ Escuela Nacional de Ingeniería Pesquera, Universidad Autónoma de Nayarit \\ Bahía de Matanchen Km 12, Carretera a los Cocos, San Blas, Nayarit 63740, Mexico \\ ${ }^{3}$ Centro de Investigaciones Biológicas del Noroeste (CIBNOR), Instituto Politécnico Nacional \\ 195 Col. Playa Palo de Sta. Rita Sur, La Paz, B.C.S. 23096, Mexico \\ Corresponding author: Alfredo Hernandez-Llamas (ahllamas04@ cibnor.mx)
}

\begin{abstract}
We used a bio-economic model to analyze the role that alternative seeding-harvesting schedules, temperature, dissolved oxygen, stocking density, and duration of cultivation play in the economic performance of semi-intensive shrimp cultivation in Mexico. The highest production was predicted for the May-August schedule (1130-2300 kg ha-1), while the lowest yields were obtained for the March-June schedule (949-1300 kg $\mathrm{ha}^{-1}$ ). The highest net revenues were projected for the August-November schedule (US\$354-1444 ha-1), while the lowest was projected for the May-August schedule (US\$330-923 ha-1). The highest annual net revenues were predicted for the combination of the March-June and August-November schedules (US\$1432-2562 ha ${ }^{-1}$ ). Sensitivity analysis indicated temperature and dissolved oxygen were the most important factors determining net revenues in March-June schedule. For the May-August and August-November schedules, stocking density was the most important factor. Duration of cultivation was the least sensitive variable. Break-even production analysis confirmed that the combination of the March-June and August-November schedules were more efficient from an economic perspective. We recommend test some ponds with higher stocking density in the March-June and August-November schedules, and in the latter case, seeding in June or July rather than August.
\end{abstract}

Keywords: bio-economics, shrimp, seeding, harvesting, water quality, aquaculture.

\section{Enfoque bio-económico para analizar el papel de programas de siembra-cosecha alternativos, calidad del agua, densidad de siembra y duración del cultivo en la producción semi-intensiva de camarón en México}

RESUMEN. Se utilizó un modelo bio-económico para analizar el papel de programas de siembra-cosecha alternativos, temperatura, oxígeno disuelto, densidad de siembra y duración del cultivo en el desempeño económico del cultivo semi-intensivo de camarón en México. La mayor producción se predijo para el programa mayo-agosto (1130-2300 $\mathrm{kg} \mathrm{ha}^{-1}$ ), mientras que los rendimientos más bajos se obtuvieron con el programa marzo-junio (949-1300 $\mathrm{kg} \mathrm{ha}^{-1}$ ). Los mayores ingresos netos se proyectaron para el programa agosto-noviembre (US\$354-1444 ha-1), mientras que los menores se proyectaron para el programa mayo-agosto (US\$330-923 ha-1). El ingreso neto anual más alto se predijo para la combinación de los programas marzo-junio y agosto-noviembre (US\$1432-2562 $\mathrm{ha}^{-1}$ ). Un análisis de sensibilidad indicó que la temperatura y oxígeno disuelto fueron los factores más importantes en determinar los ingresos netos en el programa marzo-junio. Para los programas de mayo-agosto y agosto-noviembre la densidad de siembra fue el factor más importante. La duración del cultivo fue la variable menos sensible. El análisis de la producción en el equilibrio confirmó que la combinación de los

Corresponding editor: Patricio Dantagnan 
programas marzo-junio y agosto-noviembre fue más eficiente desde una perspectiva económica. Se recomienda ensayar estanques con mayores densidades de siembra en los programas de marzo-junio y agosto-noviembre, y en el último caso, sembrar en junio o julio, en vez de agosto.

Palabras clave: bio-economía, camarón, siembra, cosecha, calidad del agua, acuicultura.

\section{INTRODUCTION}

During 2012, shrimp farms in Mexico produced 100,000 ton (CONAPESCA, 2013). About 95\% of production comes from northwestern Mexico, where semi-intensive cultivation of whiteleg shrimp Litopenaeus vannamei is most common. Several studies have been published on bio-economics of shrimp cultivation; however, there are few antecedents in the literature of bio-economic analysis of semi-intensive production of shrimp in Mexico. Using a bio-economic model, Hernandez-Llamas \& Magallón-Barajas (1991) conducted a sensitivity analysis to determine the most convenient way to improve cultivation of shrimp. Sánchez-Zazueta \& Martínez-Cordero (2009) used a bio-economic approach to evaluate the economics of farm management adjustments as a response to disease risks.

Previously, we conducted a study of semi-intensive production of shrimp in northwestern Mexico and determined that cultivation programs that seeded in spring resulted in higher production of shrimp biomass, compared with production using a cultivation program that seeded in summer (Ruiz-Velazco et al., 2013). Given the seasonality of shrimp market prices and the variability of costs among the alternative cultivation programs, the question arose whether higher production obtained when seeding in spring would also result in better economic performance, compared with seeding in summer. In this study, we use a bio-economic model to analyze the role that alternative seeding-harvesting schedules play in determining economic performance of semi-intensive shrimp cultivation in Mexico. In addition, we analyze the relative importance of management variables (stocking density and duration of cultivation) and water quality variables (temperature and dissolved oxygen) from a bio-economic perspective. This management and water quality variables are considered critical for semi-intensive production of shrimp (Hernandez-Llamas \& Villarreal-Colmenares, 1999). The bio-economic model was calibrated from databases of farms operating in the State of Nayarit under normal conditions, that is, they were not affected by disease.

\section{MATERIALS AND METHODS}

\section{Stock model and feed conversion ratio model}

A stock model was used to predict shrimp biomass as the product of individual mean weight of shrimp and the number of surviving shrimp at different harvesting times.

In a previous study (Ruiz-Velazco et al., 2013), we developed and presented the stock model together with the relationships between its parameters and water quality and management variables. The corresponding equations are presented in Table 1. Growth and survival equations were used to predict $w_{t}$ and $n_{t}$ in the stock model, and their parameters were made dependent on pond water temperature, dissolved oxygen, stocking density and duration of cultivation using 31 cases (ponds) and multiple linear equations. The same modeling approach was used for the feed conversion ratio model. The mean values of temperature and dissolved oxygen recorded throughout the cultivation periods were used for analysis.

\section{Seeding-harvesting schedules}

Three seeding-harvesting schedules were analyzed: March-June, May-August, and August-November. The values of water quality and management variables that correspond to the alternative schedules are presented in Table 2.

\section{Economic model}

Net revenue $(n r)$ was calculated in US\$ as a function of time: $n r_{t}=i_{t}-c_{t}$, where income $\left(i_{t}\right)$ is the product of shrimp biomass from the stock model and shrimp market price and $c_{t}$ are the costs considered for analysis, namely:

$c_{t}=$ cfeed $_{t}+c f e r_{t}+c e_{t}+c P L+c p p+c l+c m a+c m i+c h$

where cfeed $_{t}$ is the cost of feed, $c f e r_{t}$ is the cost of fertilizer, $c e_{t}$ is the cost of energy, $c P L$ is the cost of postlarvae, $c p p$ is the cost of pond preparation, $c l$ is the cost of labor, cma is the cost of maintenance, $\mathrm{cmi}$ is miscellaneous costs and $c h$ is the cost of harvesting.

Farmed shrimp in Mexico is typically sold according to a farm-gate base price, and the actual sale 
Table 1. Equations and functional dependence on water quality and management variables Ruiz-Velazco et al. (2013) used for the stock and feed conversion ratio models.

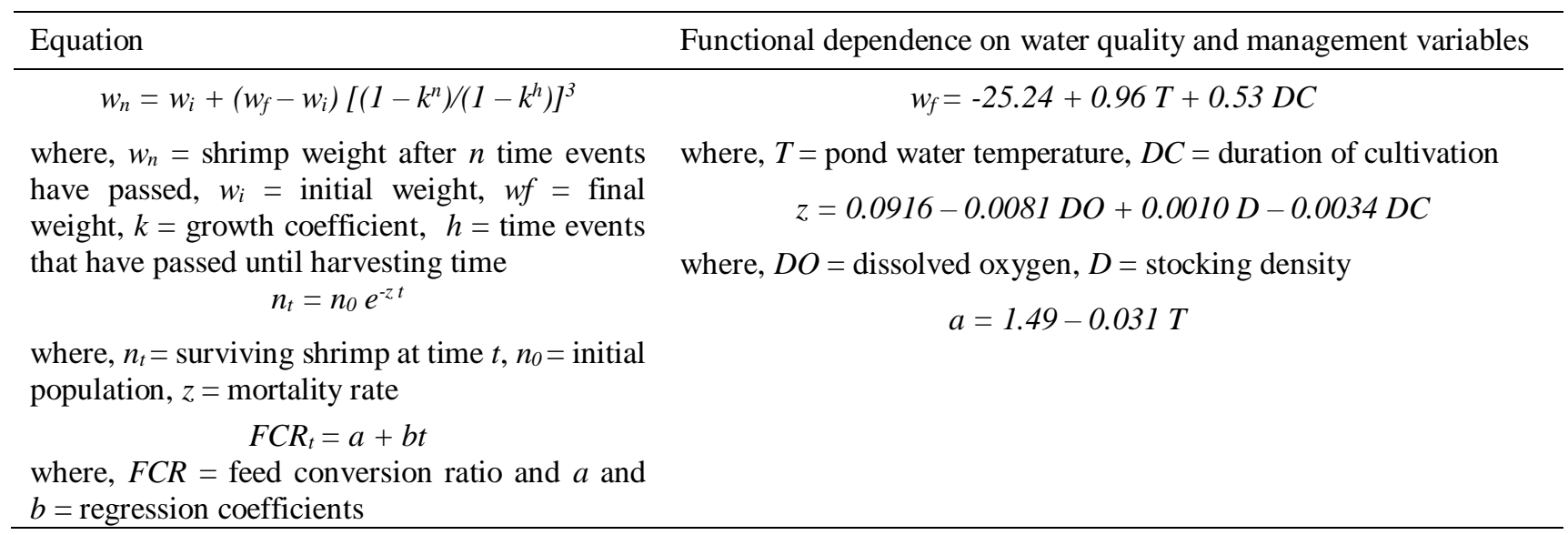

Table 2. Range values of water quality and management variables corresponding to the alternative production programs.

\begin{tabular}{|c|c|c|c|c|c|c|}
\hline \multirow{3}{*}{ Variable } & \multicolumn{6}{|c|}{ Production program } \\
\hline & \multicolumn{2}{|c|}{ March-June } & \multicolumn{2}{|c|}{ May-August } & \multicolumn{2}{|c|}{ August-November } \\
\hline & Minimum & Maximum & Minimum & Maximum & Minimum & Maximum \\
\hline Temperature $\left({ }^{\circ} \mathrm{C}\right)$ & 30.04 & 32.2 & 31.8 & 32.1 & 30.5 & 32.6 \\
\hline Dissolved oxygen $\left(\mathrm{mg} \mathrm{L}^{-1}\right)$ & 3.73 & 6.5 & 3.6 & 4.2 & 3.8 & 4.8 \\
\hline Stocking density (postlarvae $\mathrm{m}^{-2}$ ) & 13 & 17 & 16 & 37 & 14 & 25 \\
\hline Duration of cultivation (weeks) & 9.5 & 12 & 9.5 & 13 & 9 & 14 \\
\hline
\end{tabular}

price is calculated by adding, to the base price, US\$ 0.074 for every gram corresponding to the mean individual weight of shrimp. For example, if the base price is US $\$ 2.22 \mathrm{~kg}^{-1}$ and the mean weight of shrimp is $15 \mathrm{~g}$, the sale price is US\$3.7 $\mathrm{kg}^{-1}$. Shrimp price was predicted on a monthly basis from January through December, using a fourth order polynomial (Fig. 1). The estimates of costs analyzed are presented in Table 3.

Break-even production (bep) was calculated according to Parkin (1996): $b e p=c_{f} /\left(i_{s}-c_{v}\right)$, where $c_{f}$ are fixed costs, $i_{s}$ is the income per kilogram of produced shrimp and $c_{v}$ are the variable costs needed to produce a $\mathrm{km}$ of shrimp.

\section{Management schemes}

In a previous work (Ruiz-Velazco et al., 2013), we determined the combinations of stocking density and duration of cultivation that minimize and maximize production of shrimp biomass in the seeding-harvesting schedules. The lowest stocking density and the shortest duration of cultivation minimize production, whereas the highest stocking density and longest duration of cul-

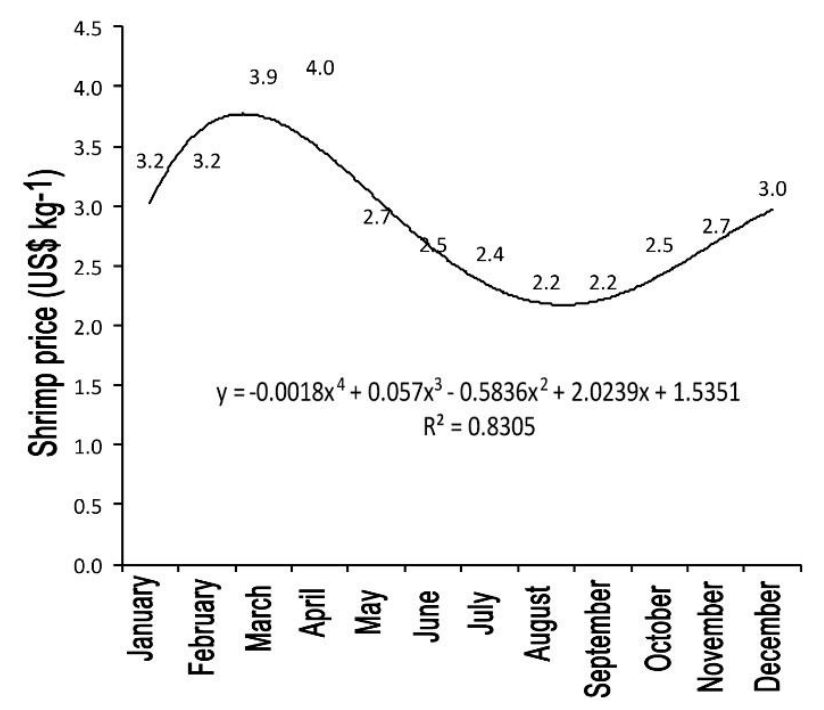

Figure 1. Seasonal variability of shrimp prices and polynomial curve fitted for prediction.

tivation maximize production. Intermediate values of the management variables were used to define complementary management schemes, and the corresponding 
Table 3. Costs considered for analysis.

\begin{tabular}{lr}
\hline Cost & US\$ \\
\hline Postlarvae $(\$ /$ thousand $)$ & 4.62 \\
Feed $\left(\$ \mathrm{~kg}^{-1}\right)$ & 0.92 \\
Fertilizers $\left(\$ \mathrm{~kg}^{-1}\right)$ & 0.92 \\
Energy $\left(\$ \mathrm{kwh}^{-1}\right)$ & 0.20 \\
Pond preparation $\left(\$ \mathrm{ha}^{-1} \mathrm{yr}^{-1}\right)$ & 115.38 \\
Labour $\left(\$ \mathrm{ha}^{-1} \mathrm{yr}^{-1}\right)$ & $2,352.00$ \\
Maintenance $\left(\$ \mathrm{ha}^{-1} \mathrm{yr}^{-1}\right)$ & 481.15 \\
Miscelaneous $\left(\$ \mathrm{ha}^{-1} \mathrm{yr}^{-1}\right)$ & 157.31 \\
Harvesting $\left(\$ \mathrm{shrimp} \mathrm{kg} \mathrm{kg}^{-1}\right)$ & 0.15 \\
\hline
\end{tabular}

production was calculated. We use a similar approach to determine if the lowest and highest net revenues would be obtained using the combinations of values of the management variables that minimized and maximized production. The combination of values for the management variables corresponding to the three schedules and management schemes are presented in Table 4.

\section{Software and sensitivity analysis}

As described in Ruiz-Velazco et al. (2013), the multiple linear regression procedure available in Stata 13 (Stata Corp, College Station, TX) was used to fit the equations that allowed predicting parameters of the stock model as a function of water quality and management variables. According to the methods described in Rencher (2002), this is a regression procedure dealing automatically with multicollinearity; tests for violation of linear regression assumptions available in Stata 13 indicated normality and homoscedasticity in the data.

Sensitivity of net revenues to changes in the values of the water quality and management variables was determined using the range of values of the variables recorded in the database. This analysis allowed us to determine the contribution, that is, the importance that each variable has on economic output. The bioeconomic model was programmed using worksheets of Excel 2007, and sensitivity analysis was conducted with procedures available in @Risk 5.5 Industrial (Palisade, Ithaca, NY).

\section{RESULTS}

Predicted shrimp production increased from management scheme 1 through management scheme 5 in all the seeding-harvesting schedules (Fig. 2). Higher yields were predicted for the May-August schedule $(1,130$ $2,300 \mathrm{~kg} \mathrm{ha}^{-1}$ ) and lower yields were predicted for the March-June schedule (949-1,300 $\left.\mathrm{kg} \mathrm{ha}^{-1}\right)$.

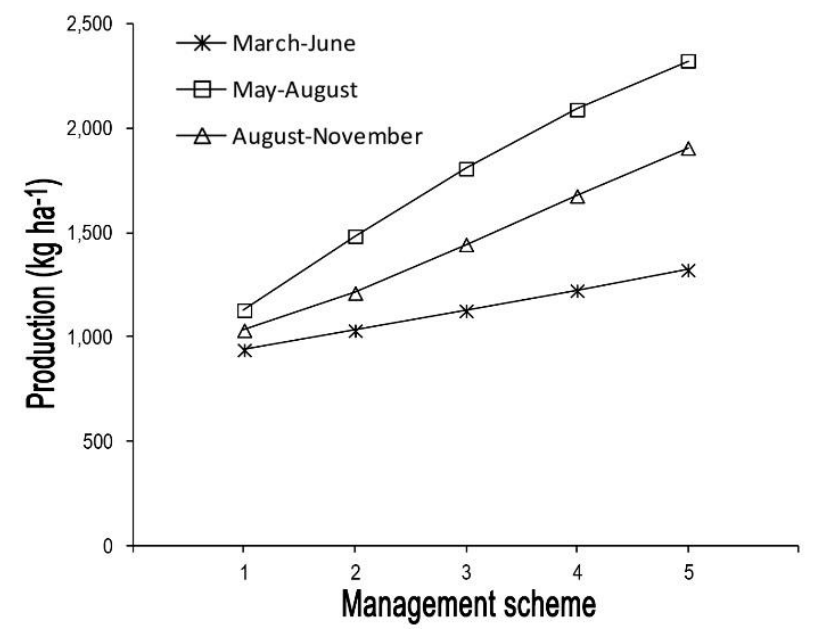

Figure 2. Shrimp production calculated for alternative management schemes and cultivation schedules.

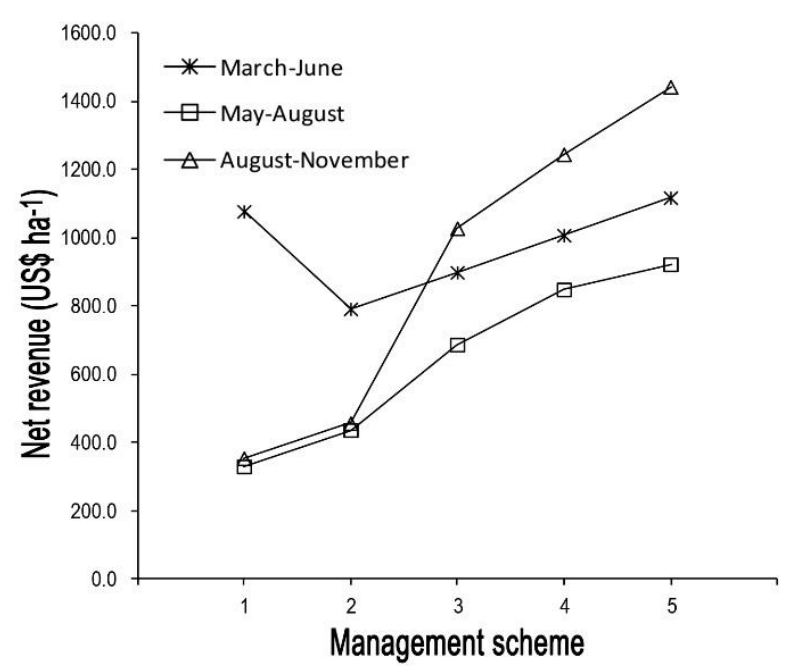

Figure 3. Net revenues calculated for alternative management schemes and three cultivation schedules.

Net revenues varied with the schedules and management schemes (Fig. 3). For March-June, revenues varied from US\$1,078 ha-1 (scheme 1) to US\$1,118 ha-1 (scheme 5); for May-August revenues varied from US\$330 ha ${ }^{-1}$ (scheme 1) to US\$923 ha ${ }^{-1}$ (scheme 5); for August-November, revenues varied from US\$354 ha ${ }^{-1}$ (scheme 1) to US\$1,444 ha- (scheme $5)$.

Annual net revenues from the combination of production schedules varied (Fig. 4). For the combination of March-June and August-November, net revenues varied from US\$1,432 $\mathrm{ha}^{-1}$ (scheme 1) to US $\$ 2,562 \mathrm{ha}^{-1}$ (scheme 5). For the combination of May-August and August-November net revenues varied from US\$684 ha ${ }^{-1}$ (scheme 1) to US\$2,367 ha ${ }^{-1}$ 
Table 4. Values of the management variables used to define the management schemes for the alternative cultivation programs.

\begin{tabular}{|c|c|c|c|c|c|c|}
\hline \multirow{3}{*}{$\begin{array}{l}\text { Management } \\
\text { schemes }\end{array}$} & \multicolumn{6}{|c|}{ Cultivation program } \\
\hline & \multicolumn{2}{|c|}{ March-June } & \multicolumn{2}{|c|}{ May-August } & \multicolumn{2}{|c|}{ August-November } \\
\hline & $\begin{array}{l}\text { Stocking density } \\
\left(\text { postlarvae } \mathrm{m}^{-2}\right)\end{array}$ & $\begin{array}{c}\text { Duration of } \\
\text { cultivation } \\
\text { (weeks) }\end{array}$ & $\begin{array}{l}\text { Stocking density } \\
\left(\text { postlarvae } \mathrm{m}^{-2}\right)\end{array}$ & $\begin{array}{c}\text { Duration of } \\
\text { cultivation } \\
\text { (weeks) }\end{array}$ & $\begin{array}{l}\text { Stocking density } \\
\left(\text { postlarvae } \mathrm{m}^{-2}\right)\end{array}$ & $\begin{array}{c}\text { Duration of } \\
\text { cultivation } \\
\text { (weeks) }\end{array}$ \\
\hline 1 & 13 & 9.5 & 16 & 9.5 & 14 & 9 \\
\hline 2 & 14 & 10.125 & 21.25 & 10.375 & 16.75 & 10.25 \\
\hline 3 & 15 & 10.75 & 26.5 & 11.25 & 19.5 & 11.5 \\
\hline 4 & 16 & 11.375 & 31.75 & 12.125 & 22.25 & 12.75 \\
\hline 5 & 17 & 12 & 37 & 13 & 25 & 14 \\
\hline
\end{tabular}

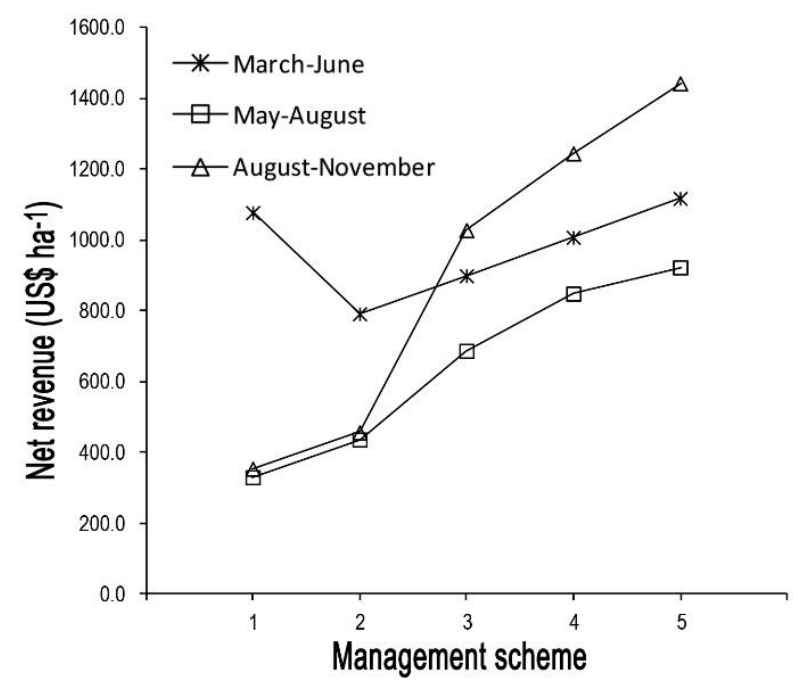

Figure 4. Net revenues calculated for alternative management schemes and combinations of cultivation schedules.

(scheme 5). The differences in net revenue when using schemes 1 and 5 represent increases of $246.0 \%$ for the first combination and $78.9 \%$ for the second one.

Sensitivity analysis indicated that temperature and dissolved oxygen were the most influential factors determining net revenues in the March-June schedule (Fig. 5). Stocking density was the most influential factor in the May-August and August-November schedules. Duration of cultivation was the least sensitive variable in the schedules.

Break-even production analysis showed that the combination of the March-June and August-November schedules was more efficient, from the economic point of view, than the combination of May-August and August-November. For the first combination, and depending on the management scheme, it was necessary to produce 543-647 $\mathrm{kg} \mathrm{ha}^{-1} \mathrm{yr}^{-1}$ to obtain a break-even condition, whereas for the second combination it was necessary to produce $766-936 \mathrm{~kg}$
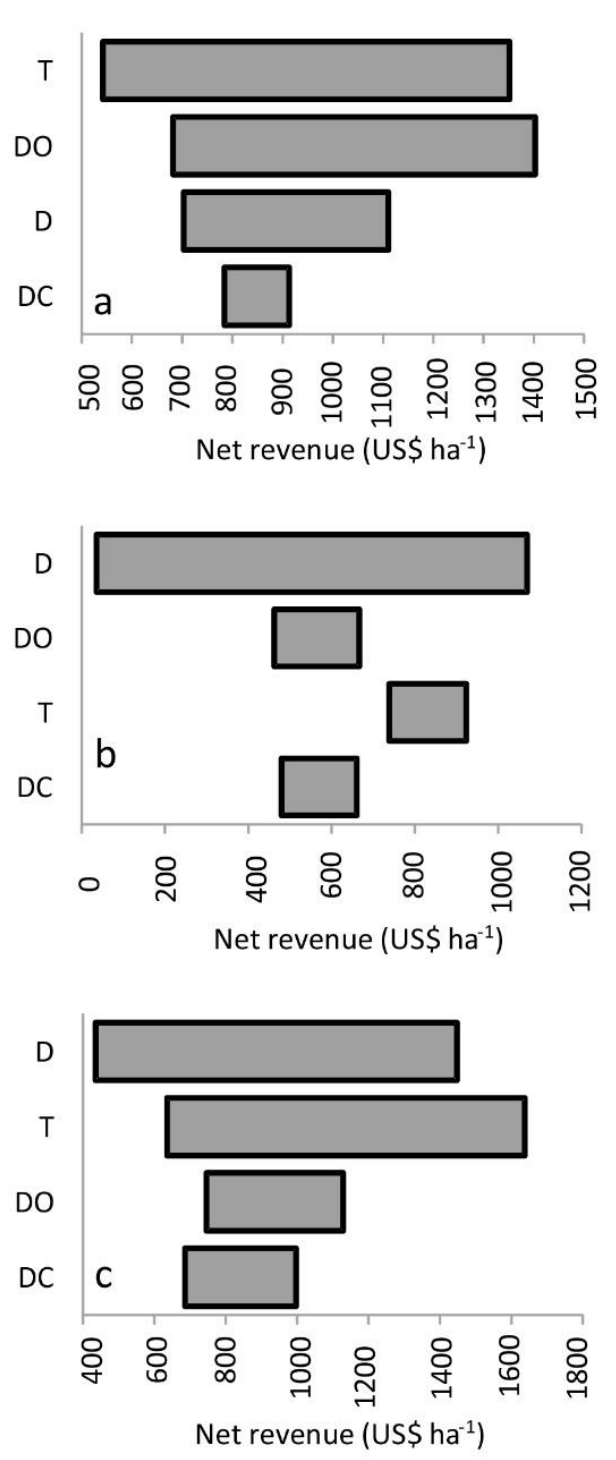

Figure 5. Sensitivity of net revenues to temperature (T), dissolved oxygen (DO), stocking density (D), and duration of cultivation (DC) for three schedules: a) MarchJune, b) May-August, and c) August-November. Wider bars indicate higher sensitivity. 


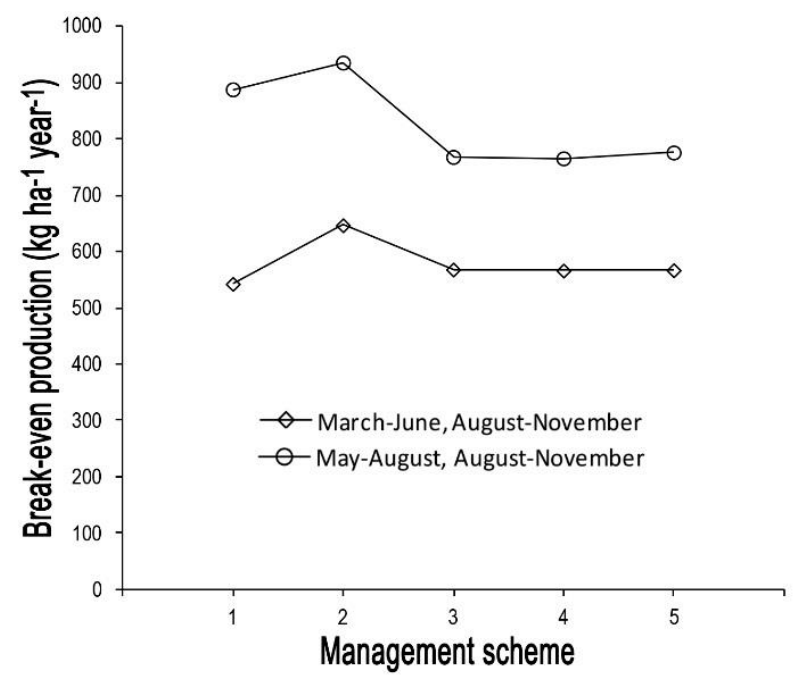

Figure 6. Break-even production calculated for alternative management schemes and combinations of cultivation programs.

$\mathrm{ha}^{-1} \mathrm{yr}^{-1}$ (Fig. 6). This means that it was necessary to use at least $17.6 \%-28.8 \%$ (first combination) and $18.3 \%-41.1 \%$ (second combination) of the total production capacity to obtain a break-even condition.

\section{DISCUSSION}

The highest net revenues were obtained for the AugustNovember schedule. Using this schedule, together with the March-June schedule resulted in the highest annual net revenues. The May-August schedule yielded the highest biomass production of shrimp, although it also produced the lowest net revenues, indicating that economic performance of the seeding-harvesting schedules was strongly influenced by the seasonal variability of shrimp prices.

The importance of shrimp price cannot be overemphasized. Previous analyses show that it is a major factor determining economic outcome of semiintensive and intensive cultivation of shrimp (HernandezLlamas \& Magallón-Barajas, 1991; Hernandez-Llamas \& Zarain-Herzberg, 2011; Hernandez-Llamas et al., 2013). In this study, net revenues rose as stocking density and duration of cultivation increased from management scheme 1 to scheme 5, with the exception of scheme 1 of the March-June schedule. In this case, the use of the shortest cultivation period simulated harvesting in May, when shrimp prices are still relatively high, resulting in net revenue similar to that obtained when using the best scheme 5 . The best economic performance occurred for the AugustNovember schedule, when shrimp prices tend to rise (September to November). The May-August schedule had the highest stocking densities and produced the highest shrimp biomass; however, it produced the poorest economic output. This was a consequence of low shrimp prices in August (lowest during the year). The relevance of shrimp price for designing and scheduling cultivation programs calls for implementing detailed databases of shrimp prices and accounting for changes in price on a weekly, rather than a monthly basis.

Sensitivity analysis indicated the relevance of water quality and management variables in determining net revenues. The relevance of the variables is dependent on: (1) the role they play within the structure of the bioeconomic model, and (2) variability they show in the database, which reflects what historically has occurred at the farms that were studied. Stocking density was most important, except in the March-June schedule when the range in stocking density was narrow (13 to 17 postlarvae $\mathrm{m}^{-2}$ ). In contrast, the range of dissolved oxygen for this production schedule is wider, compared to the two other schedules, resulting in dissolved oxygen as the most important factor during MarchJune. Duration of cultivation was consistently the least sensitive variable in all cases, indicating that farmers prefer to keep this management factor within narrow limits.

Ruiz-Velazco (2011) calculated that at least $43 \%$ of total production capacity should be used to obtain a break-even situation for intensive production of shrimp L. vannamei. Hernandez-Llamas et al. (2004) calculated that $53 \%$ of the total production capacity was necessary for a break-even situation for the intensive production of the blue shrimp Litopenaeus stylirostris. For semi-intensive production of whiteleg shrimp $L$. vannamei, we calculated a lower percentage than the amount previously reported, indicating possible operation and economic advantages of semi-intensive cultivation of whiteleg shrimp.

We found that the highest net revenues were obtained by using extended durations of cultivation and the highest stocking densities (management scheme 5). This agrees with reports on shrimp cultivation under intensive conditions, in floating cages and ponds (HernandezLlamas \& Zarain-Herzberg 2011; Hernandez-Llamas et al., 2013).

\section{CONCLUSION}

From an economic perspective, we conclude that the combination of the March-June and August-November schedules is preferable to the combination of MayAugust and August-November. We recommend testing some ponds with higher stocking density during the March-June and August-November schedules and, for 
the latter schedule, seeding earlier in June or July rather than August.

\section{ACKNOWLEDGEMENTS}

The authors are grateful to the shrimp farmers in the State of Nayarit for their cooperation, especially the firm of Encarnación Torres García. Ira Fogel of CIBNOR provided valuable editorial services. M.E.P. was a recipient of a graduate fellowship from Consejo Nacional de Ciencia y Tecnología of Mexico.

\section{REFERENCES}

Comisión Nacional de Acuacultura y Pesca (CONAPESCA). 2013. Anuario estadístico de acuacultura y pesca. [http://www.conapesca.sagarpa.gob.mx/wb/ cona/cona_anuario_estadistico_de_pesca]. Reviewed: 12 May 2014.

Hernandez-Llamas, A. \& F.J. Magallón-Barajas. 1991. Análisis bioeconómico del cultivo del camarón azul (Penaeus stylirostris) con fertilizantes orgánicos e inorgánicos y alimentación balanceada. Invest. Mar. CICIMAR, 6: 267-281.

Hernandez-Llamas, A. \& H. Villarreal-Colmenares. 1999. TEMA: a software reference to shrimp Litopenaeus vannamei farming practices. Aquacult. Econ. Manage., 3(3): 267-280.

Hernandez-Llamas, A. \& M. Zarain-Herzberg. M. 2011. Bioeconomic modeling and risk analysis of raising shrimp Litopenaeus vannamei in floating cages in northwestern Mexico: assessment of hurricane hazard, stochastic variability of shrimp and feed prices, and zootechnical parameters. Aquaculture, 314: 61-268.

Received: 17 May 2014; Accepted: 24 December 2014
Hernandez-Llamas, A., J.M.J. Ruiz-Velazco \& V.M. Gómez-Muñoz. 2013. Economic risk associated with white spot disease and stochastic variability in economic, zootechnical and water quality parameters for intensive production of Litopenaeus vannamei. Rev. Aquacult., 5: 121-131.

Hernandez-Llamas, A., A. Gonzalez-Becerril, S. HernandezVazquez \& S. Escutia-Zuñiga. 2004. Bioeconomic analysis of intensive production of the blue shrimp Litopenaeus stylirostris (Stimpson). Aquacult. Res., 35: 103-111.

Parkin, M. 1996. Microeconomía. Addison-Wesley Iberoamericana, México DF, 247 pp.

Rencher, A.A. 2002. Methods of multivariate analysis. John Wiley \& Sons, New York, 2: 708 pp.

Ruiz-Velazco, J.M.J. 2011. Modelo bioeconómico para el análisis del riesgo del cultivo intensivo de camarón blanco (Litopenaeus vannamei). Doctoral Thesis. Centro Interdisciplinario de Ciencias Marinas, Instituto Politécnico Nacional, La Paz, B.C.S., 127 pp.

Ruiz-Velazco, J.M.J., M. Estrada-Pérez, A. HernandezLlamas, J.T. Nieto-Navarro \& E. Peña-Messina. 2013. Stock model and multivariate analysis for prediction of semi-intensive production of shrimp Litopenaeus vannamei as a function of water quality and management variables: a stochastic approach. Aquacult. Eng., 56: 34-41.

Sánchez-Zazueta, E. \& F.J. Martínez-Cordero. 2009. Economic risk assessment of a semi-intensive shrimp farm in Sinaloa, Mexico. Aquacult. Econ. Manage., 13: 312-327. 